\title{
TANGGAPAN WISATAWAN TERHADAP OBYEK WISATA PANTAI TAKISUNG DI KABUPATEN TANAH LAUT, KALIMANTAN SELATAN
}

\author{
Sidharta Adyatma \\ Pendidikan Geografi FKIP Universitas Lambung Mangkurat, \\ Kalimantan Selatan, Indonesia
}

\begin{abstract}
Abstrak
Penelitian ini bertujuan mengetahui tanggapan wisatawan domestik terhadap sarana, prasarana dan keadaan obyek wisata di Pantai Takisung di Kabupaten Tanah Laut, Kalimantan Selatan. Penelitian dilakukan dengan metode deskriptif kuantitatif. Sampel yang dipergunakan adalah wisatawan yang berkunjung selama 12 hari dengan 300 responden. Instrumen yang digunakan adalah data primer dan data sekunder. Data primer diperoleh dari kuesioner dan wawancara, data sekunder yang didapat dari dokumen hasil penelitian. Hasil penelitian menunjukkan bahwa Sarana dan prasarana obyek wisata Pantai Takisung untuk alat transportasi umum perlu diadakan dan perlu penambahan fasilitas menara pandang untuk menikmati pemandangan alam Pantai Takisung. Diperlukan penyediaan beberapa sarana air mancur untuk membilas, penambahan jumlah dan jenis pertunjukan di panggung hiburan serta penambahan petugas kebersihan.
\end{abstract}

Kata kunci: obyek wisata, Pantai Takisung, tanggapan wisatawan

\section{Abstract}

The research aim is to know domestic tourists respons towards facility, prefacility, and condition of Takisung beach. Method in this research is quantitative descriptive method. Population of this research is the tourists who visited Takisung beach for 12 days with 300 respondents. The instruments used was the premier and the seconder data, the premier data was got from questioner and interview, the seconder data was got from document study. The result of research indicates that facility, prefacility and condition of Takisung beach must be kept, increased, and managed well and professional so the number of tourists can increase and have high intention to revisit Takisung beach.

Keywords: recreation object, takisung beach, tourists respons

\section{PENDAHULUAN}

Objek dan daya tarik wisata Obyek dan daya tarik wisata dalam Undang-Undang Pariwisata Nomor 9 Tahun 1990 dinyatakan sebagai tempat yang menjadi sasaran perjalanan wisata. Sasaran perjalanan meliputi ciptaan Tuhan Yang Maha Esa, yang berwujud keadaan alam serta flora dan fauna, seperti pemandangan alam, panorama indah, hutan rimba dengan tumbuhan hutan tropis, serta binatang-binatang langka, karya manusia yang berwujud museum, peninggalan purbakala, peninggalan sejarah, seni budaya, wisata agro (pertanian), wisata tirta (air), wisata petualangan, taman rekreasi, dan tempat hiburan, sasaran wisata minat khusus, seperti: berburu, mendaki gunung, gua, industri dan kerajinan, tempat perbelanjaan, sungai air deras,

\footnotetext{
* Corresponding Address:

Sidharta Adyatma

Email : adyatma_sidharta@yahoo.com

Address : Pendidikan Geografi FKIP Universitas Lambung Mangkurat
}

tempat-tempat ibadah, tempat-tempat ziarah dan lain-lain [1].

Wisatawan melakukan perjalanan wisata, terlebih dahulu ingin mengetahui tentang fasilitas transportasi ke daerah tujuan wisata yang ingin dikunjungi, fasilitas akomodasi untuk tempat tinggal sementara di daerah tujuan yang dikunjungi, fasilitas pelayanan katering (catering service), obyek dan atraksi wisata yang ada di daerah tujuan yang akan dikunjungi, aktivitas rekreasi yang dapat dilakukan di tempat yang akan dikunjungi tersebut, fasilitas perbelanjaan untuk cinderamata pada khususnya, tempat atau toko untuk membeli atau reparasi kamera dan mencetak film hasil pemotretan. Prasarana dan sarana kepariwisataan yang harus diadakan sebelum mempromosikan suatu daerah tujuan wisata, prasarana (infrastructures) adalah semua fasilitas yang dapat memungkinkan proses perekonomian berjalan dengan lancar sedemikian rupa, sehingga dapat memudahkan manusia untuk dapat memenuhi kebutuhan[2]. 
Jenis wisata yang ada di Provinsi Kalimantan Selatan diantaranya adalah Pasar Terapung dan Pulau Kembang yang ada di Kota Banjarmasin. Pendulangan dan Pasar Intan di Kabupaten Banjar, Pantai Takisung, Pantai Swarangan, Pantai Batakan, Air Terjun Bajuin di Kabupaten Tanah Laut, Air Panas Tanuhi dan Hutan Loksado yang berada di Kabupaten Hulu Sungai Selatan, Pagat di Hulu Sungai Tengah, Candi Agung di Hulu Sungai Utara dan Pantai Gedambaan di Kabupaten Kotabaru. Pantai Takisung terletak 22 $\mathrm{km}$ dari Pelaihari atau $87 \mathrm{~km}$ dari Kota Banjarmasin, dengan sarana dan prasarana, yaitu jalan yang beraspal menuju obyek wisata pantai takisung, wc umum, kamar mandi, areal parkir, pasar ada pedagang ikan dan buah-buahan, pedagang makanan, minuman dan pedagang cinderamata, panggung, halte, pos polisi, shalter (tempat berteduh), restoran dan tempat bermain [3].

Pengunjung Pantai Takisung berdasarkan data Dinas Pariwisata Kabupaten Tanah Laut mengalami peningkatan dalam 5 tahun terakhir, yaitu pada tahun 2000 jumlah pengunjung 26.575 orang, tahun 2001 jumlah pengunjung sebanyak 35.410 wisatawan, tahun 2002 jumlah pengunjung sebanyak 47.149 wisatawan, tahun 2003 jumlah pengunjung sebanyak 51.948 wisatawan, tahun 2004 jumlah pengunjung sebanyak 85.448 wisatawan, tahun 2005 jumlah pengunjung sebanyak 73.631 wisatawan, tahun 2006 jumlah pengunjung sebanyak 79.942 wisatawan dan tahun 2007 jumlah pengunjung sebanyak 107.123 wisatawan [4]. Peningkatan pengunjung di obyek wisata Pantai Takisung diharapkan diimbangi dengan penyediaan fasilitas sarana dan prasarana yang memadai bagi wisatawan yang berkunjung. Berdasarkan hal tersebut diperlukan penelitian untuk mengetahui tanggapan wisatawan domestik terhadap sarana, prasarana dan keadaan obyek wisata di obyek Wisata Pantai Takisung di Kabupaten Tanah Laut.

\section{METODE PENELITIAN}

Populasi dalam penelitian adalah para wisatawan yang berkunjung ke obyek wisata Pantai Takisung. Teknik pengambilan sampel menggunakan teknik sampel bertujuan (purposive sampling) dengan cara mengambil subjek yang didasarkan atas adanya tujuan tertentu. Sampel penelitian adalah wisatawan yang berkunjung selama hari libur yang diambil secara acak, yaitu tiap hari minggu selama 12 minggu dan diperoleh responden sebanyak 300 responden.
Jenis data yang digunakan adalah data primer dan sekunder, data primer diperoleh melalui observasi, kuesioner dan wawancara untuk memperoleh tanggapan responden tentang ketersediaan dan kondisi sarana serta prasarana. Sarana dan prasarana tersebut meliputi jenis alat transportasi, kondisi jalan, keadaan pasar, keadaan MCK, tempat parkir, keadaan tempat berteduh, pos polisi, keadaan tempat bermain anak, penginapan, serta ketersediaan ban dan perahu karet. Data primer lainnya adalah keadaan pantai Takisung, meliputi pemandangan alam, keadaan air laut, atraksi wisata, keamanan, kebersihan dan keadaan gelombang. Data sekunder diperoleh dari studi dokumen yang terdiri dari data jumlah pengunjung, peta administrasi dan profil Kecamatan Takisung.

Analisis data yang digunakan dalam penelitian ini adalah deskriptif kuantitatif, yaitu menjabarkan berdasarkan hasil wawancara dan hasil distribusi frekuensi dari kuesioner yang telah diperoleh dan dilakukan pengecekan data, pemberian kode dan tabulasi.

\section{HASIL DAN PEMBAHASAN}

Berdasarkan hasil kuesioner dan wawancara dengan responden sebanyak 300 wisatawan, maka tanggapan responden terhadap sarana dan prasarana dan keadaan pantai Takisung dapat diuraikan sebagai berikut:

\section{A. Sarana dan Prasarana Obyek Wisata Pantai Takisung}

1. Jenis Alat Transportasi yang Digunakan Menuju Obyek Wisata Pantai Takisung

Jumlah wisatawan yang berkunjung ke Pantai Takisung tergantung pada ketersediaan dan mobilitas alat transportasi, karena sangat mempengaruhi keinginan orang untuk melakukan perjalanan wisata. Tanggapan responden tentang jenis alat transportasi yang dipergunakan menuju obyek wisata sebanyak 252 (84\%) responden menggunakan kendaraan pribadi berupa mobil dan sepeda motor, sedang sebanyak 48 (16\%) responden menggunakan kendaraan umum seperti bis dan mobil carteran. Kendaraan pribadi dipergunakan wisatawan karena lebih nyaman dan mudah dalam menuju serta pulang dari tempat tujuan serta tidak tergantung pada waktu, selain itu biaya yang dikeluarkan lebih murah dengan menghemat antara Rp. 10.000,-- sampai Rp. 30.000,- per orang dibandingkan memakai jasa kendaraan umum biayanya mahal dan terikat oleh waktu carteran. 
Biaya carteran mahal karena pemerintah daerah belum menyediakan alat trasportasi umum yang khusus melayani dari terminal Pelaihari menuju obyek wisata pantai Takisung, apabila tersedia dan murah maka diperkirakan pengunjung ke Pantai Takisung akan meningkat khususnya pada Sabtu, Minggu dan libur nasional.

\section{Kondisi Jalan Menuju Obyek Wisata Pantai} Takisung

Tanggapan responden terhadap kondisi jalan menuju obyek wisata Pantai Takisung sebanyak 240 (80\%) responden menyatakan bahwa kondisi jalan beraspal mulus dan nyaman tanpa ada lobang yang berarti karena baru dibangun dan diperlebar, sedang sebanyak 60 (20\%) responden menyatakan bahwa kondisi jalan beraspal dan kurang nyaman karena jalan tidak rata disebabkan adanya lobang atau bergelombang, sehingga mengganggu kenyamanan penumpang. Perawatan dan pelapisan jalan menuju obyek wisata Pantai Takisung oleh pemerintah daerah diperlukan secara berkala, hal ini untuk mengantisipasi kerusakan yang terjadi setiap musim penghujan dan memberikan kenyamanan bagi wisatawan yang berkunjung.

\section{Keadaan Pasar di Obyek Wisata Pantai Takisung}

Tanggapan responden terhadap kondisi pasar di obyek wisata Pantai Takisung sebanyak 174 (58\%) responden menyatakan bahwa keadaan pasar telah lengkap tersedia warung atau kios untuk para pedagang cinderamata, hasil laut dan hasil pertanian sehingga wisatawan mudah mendapatkan oleh-oleh yang diinginkan dari obyek wisata. Sebanyak 126 (42\%) responden menyatakan bahwa keadaan pasar belum lengkap dan teratur, karena belum banyak tersedia warung atau kios rumah makanan khususnya menyajikan makanan hasil laut untuk dinikmati sambil beristirahat, selain itu keberadaan pedagang yang berjualan tidak teratur. Sebagian pedagang menempati tempat yang sudah disediakan, tetapi banyak pedagang berada diluar lokasi pasar dan masuk ke areal pantai, sehingga mengganggu wisatawan yang sedang rekreasi. Pengaturan dan penertiban pedagang oleh pengelola obyek wisata perlu dilakukan agar keteraturan pasar dan kenyamanan wisatawan terjaga.

Tanggapan responden terhadap kebersihan pasar di obyek wisata Pantai Takisung sebanyak 132 (44\%) responden menyatakan bahwa saat datang keadaan pasar masih bersih tidak dijumpai sampah yang berserakan, sedang sebanyak 168 (56\%) responden menyatakan bahwa banyak keadaan pasar kotor dan banyak dijumpai sampah yang berserakan yaitu saat wisatawan mulai berdatangan berbelanja di pasar. Menjaga kebersihan pasar merupakan bagian dari obyek wisata. Penyediaan tempat sampah dan petugas kebersihan sangat diperlukan, selain itu pengarahan dan pemasangan papan pengumuman agar pedagang dan wisatawan membuang sampah pada tempatnya perlu digalakkan agar kebersihan pasar dan sekitar pantai terjaga.

\section{Keadaan MCK (Mandi, Cuci, Kakus)}

Tanggapan responden terhadap keadaan MCK di obyek wisata Pantai Takisung sebanyak 156 (52\%) responden menyatakan bahwa MCK dalam keadaan masih bersih dan tidak bau, hal ini karena di waktu pagi hari belum banyak wisatawan yang memanfaatkan MCK, sedang sebanyak 144 (48\%) responden menyatakan bahwa MCK dalam keadaan kotor dan berbau, hal ini terjadi mulai siang hari karena petugas jaga tidak langsung mengecek kebersihan dan membersihkan MCK setelah tidak dipakai wisatawan tetapi hanya memungut biaya saja. Pengelola obyek wisata perlu mendisiplinkan petugas penjaga agar tidak hanya menjaga dan memungut biaya tetapi juga membersihkan MCK secara teratur.

\section{Keadaan Tempat Parkir Obyek Wisata Pantai Takisung}

Tempat parkir obyek wisata Pantai Takisung cukup luas dan dapat menampung sekitar 500 berbagai jenis ukuran kendaraan. Tanggapan responden terhadap keamanan tempat parkir di obyek wisata Pantai Takisung sebanyak 210 (70\%) responden menyatakan tempat parkir aman dan sebanyak 90 (30\%) responden menyatakan tempat parkir kurang aman. Tanggapan responden terhadap pengaturan tempat parkir di obyek wisata Pantai Takisung sebanyak 180 (60\%) responden menyatakan susunan parkir teratur dan sebanyak 120 (40\%) responden menyatakan susunan parkir kurang teratur. Pengelola obyek wisata perlu menambah dan mendisiplinkan petugas parkir khususnya disaat musim liburan dan banyak wisatawan yang berkunjung, sehingga keamanan dan kerapihan pengaturan tempat parkir kendaraan terjaga dan dapat memuat banyak kendaraan.

6. Keadaan Shelter (Tempat Berteduh) di Obyek Wisata Pantai Takisung

Jumlah shelter di obyek wisata Pantai Takisung sebanyak 10 shelter dengan kondisi permanen. Baru dilakukan perbaikan atap dan cat shelter. Tanggapan responden terhadap 
jumlah shelter di obyek wisata Pantai Takisung sebanyak 246 (82\%) responden menyatakan jumlahnya kurang, sedang sebanyak 44 (18\%) responden menyatakan jumlahnya sudah cukup, hal ini karena banyak masyarakat yang membuat shelter tidak permanen yang terbuat dari tenda. Tenda dibuat penduduk dekat dengan pantai sehingga wisatawan lebih suka menyewa dan memakai tenda-tenda masyarakat dari pada shelter yang sudah disediakan, karena wisatawan lebih merasa nyaman di tenda sambil bersantai, tidur-tiduran, makan bersama dan mudah mengawasi anggota keluarga bermain di pantai. Jumlah shelter permanen perlu ditambah khususnya mengantisipasi disaat musim penghujan dan angin, karena shelter tidak permanen biasanya tidak mampu melindungi wisatawan dari terpaan angin yang kencang dan hujan yang cukup deras.

\section{Keadaan Pos Polisi di Obyek Wisata Pantai} Takisung

Pos Polisi di Obyek Wisata Pantai Takisung bangunannya relatif baru dan baik, berdasarkan tanggapan responden terhadap keberadaan polisi di Pos Polisi sebanyak 186 (62\%) responden menyatakan polisi selalu ada di Pos Polisi, sedang sebanyak 114 (38\%) responden menyatakan Pos Polisi dalam keadaan kosong (tidak ada polisi), hal ini kemungkinan ketiadaan polisi karena sedang patroli di luar. Oleh karena itu, Pos Polisi di Obyek Wisata Pantai Takisung diharapkan selalu ada salah satu anggota yang piket untuk menampung dan menindaklanjuti keluhan dan masalah keamanan yang dialami wisatawan.

\section{Keadaan Alat Bermain Anak di Obyek Wisata Pantai Takisung}

Alat bermain anak di Obyek Wisata Pantai Takisung dalam kondisi yang baik dan layak dipakai. Tanggapan responden terhadap jumlah dan jenis alat bermain yang tersedia sebanyak 156 (52\%) responden menyatakan jumlah dan jenisnya mencukupi, sedang sebanyak 144 (48\%) responden menyatakan jumlah dan jenisnya kurang mencukupi, hal ini kemungkinan terjadi disaat musim liburan dan banyak wisatawan yang berkunjung sehingga banyak anak-anak harus mengantri bergantian untuk bermain.

\section{Keadaan Penginapan di Obyek Wisata Pantai Takisung}

Bangunan penginapan di Obyek Wisata Pantai Takisung relatif baru dan memadai untuk menginap. Tanggapan responden terhadap kondisi penginapan yang tersedia sebanyak 54 (18\%) responden menyatakan kondisinya terawat, sedang sebanyak 246 (82\%) responden menyatakan kondisinya kurang terawat, hal ini berkaitan dengan keadaan MCK dan penyediaan air bersih serta kebersihan tempat tidur dan keberadaan meja kursi tamu yang tidak lengkap. Pengelolaan penginapan di Obyek Wisata Pantai Takisung perlu lebih profesional supaya wisatawan dapat lebih lama tinggal dan menginap, sehingga dapat meningkatkan pendapatan Obyek Wisata Pantai Takisung.

10. Jumlah Ban Karet dan Perahu Karet di Obyek Wisata Pantai Takisung

Tanggapan responden terhadap jumlah dan kondisi ban karet dan perahu karet yang disewakan di obyek wista Pantai Takisung sebanyak 216 (72\%) responden menyatakan bahwa jumlahnya cukup banyak dan kondisinya baik, sedang 84 (28\%) responden menyatakan bahwa jumlahnya cukup banyak tetapi kondisinya kurang baik, hal ini diindikasikan dengan adanya bekas tambalan dan perahu karet tidak standar. Penyewaan perahu karet diharapkan dilengkapi atau satu paket dengan jaket pelampung demi keamanan, karena perahu karet tidak standar dan dapat bergerak jauh menuju laut yang lebih dalam.

\section{B. Keadaan Pantai Takisung}

\section{Pemandangan Alam di Pantai Takisung}

Sebanyak 198 (66\%) responden menyatakan bahwa pemandangan alam tampak bagus, karena ada siring dan pohon kelapa dipesisir pantai serta dapat melihat matahari terbit dan tenggelam, sedang 102 (34\%) responden menyatakan bahwa pemandangan alam tampak kurang bagus karena terganggu adanya pohon kelapa yang tumbang terkena abrasi pantai pada saat angin timur bertiup kencang. Penambahan fasilitas menara pandang untuk menikmati pemandangan alam Pantai Takisung dan peremajaan kembali pohon kelapa yang tumbang sangat diperlukan untuk menambah daya tarik bagi wisatawan.

\section{Keadaan Air Laut di Pantai Takisung}

Tanggapan responden terhadap keadaan air laut di Pantai Takisung sebanyak 36 (12\%) responden menyatakan bahwa air laut keruh dan berwarna kekuningan, sedang sebanyak 264 (88\%) responden menyatakan bahwa air laut sangat keruh dan berwarna kecoklatan, hal ini karena Pantai Takisung berdekatan dengan muara Sungai Barito dan Kapuas yang berada di sebelah barat Pantai Takisung banyak membawa hasil sedimentasi dari daerah hulu, sehingga apabila musim penghujan dan arus bergerak sepanjang pantai dari barat menuju ke timur air akan semakin keruh. Air laut yang keruh dapat menyebabkan gatal dan kotor pakaian, sehingga 
penyediaan beberapa sarana air mancur untuk membilas badan wisatawan perlu diadakan supaya kotoran yang menempel tidak membuat gatal wisatawan.

\section{Atraksi Wisata di Pantai Takisung}

Atraksi wisata di Pantai Takisung dipentaskan di panggung hiburan yang telah disediakan. Tanggapan responden terhadap kegiatan atraksi di Pantai Takisung sebanyak 192 (64\%) responden menyatakan bahwa sering diadakan pertunjukan piano tunggal dan karaoke di harihari libur besar, sedang sebanyak 108 (36\%) responden menyatakan bahwa jarang diadakan pertunjukan. Penambahan jumlah dan jenis pertunjukan di panggung hiburan perlu ditingkatkan khususnya pada hari minggu dan libur nasional misalnya diisi dengan pertunjukan dari kesenian daerah setempat untuk melestarikan budaya.

\section{Keamanan di Pantai Takisung}

Tanggapan responden terhadap keamanan di Pantai Takisung sebanyak 198 (66\%) responden menyatakan bahwa keamanan sudah baik, karena tidak pernah ada yang kehilangan barang berharga pada saat ditinggal bermain di pantai, sedang sebanyak 102 (34\%) responden menyatakan bahwa keamanan kurang baik, karena tidak tampak adanya polisi atau satpam dan petugas penyelamat yang berjaga-jaga disekitar pantai. Patroli rutin oleh polisi atau satpam dan petugas penyelamat perlu diadakan di sepanjang pantai agar wisatawan merasa aman, nyaman dan terlindungi dari bahaya pencurian dan tenggelam.

\section{Kebersihan Pantai Takisung}

Tanggapan responden terhadap kebersihan pesisir Pantai Takisung sebanyak 144 (48\%) responden menyatakan bahwa pesisir Pantai Takisung dalam keadaan bersih tidak ada sampah berserakan, hal ini terjadi disaat pagi hari sebelum banyak wisatawan berdatangan, sedang sebanyak 156 (52\%) responden menyatakan bahwa pesisir Pantai Takisung dalam keadaan kotor dan banyak sampah berserakan, hal ini terjadi saat siang dan sore hari setelah banyak wisatawan berdatangan karena kepedulian wisatawan membuang sampah pada tempatnya kurang. Pengadaan tong-tong sampah, papan pengumuman "membuang sampah pada tempatnya" perlu diperbanyak dan petugas kebersihan perlu dijadwal rutin agar pesisir Pantai Takisung tetap terjaga kebersihannya dan tampak asri.

\section{Keadaan Gelombang Pantai Takisung}

Tanggapan responden terhadap keadaan gelombang Pantai Takisung sebanyak 54 (18\%) responden menyatakan bahwa keadaan gelombang Pantai Takisung agak tinggi, hal ini terjadi disaat laut pasang dan bertiup angin timur yang kencang, sedang sebanyak 146 (82\%) responden menyatakan bahwa keadaan gelombang Pantai Takisung rendah, hal ini terjadi disaat laut sedang surut dan tiupan angin lemah. Pengawasan pada para wisatawan yang sedang mandi saat laut pasang agar terhindar dari bahaya terseret ombak.

\section{KESIMPULAN}

1. Sarana dan prasarana obyek wisata Pantai Takisung untuk alat transportasi umum perlu dilakukan perawatan dan pelapisan jalan secara berkala menuju obyek wisata Pantai Takisung, pengaturan dan penertiban pedagang oleh pengelola obyek wisata perlu dilakukan agar keteraturan pasar dan kenyamanan wisatawan terjaga, MCK secara teratur perlu dibersihkan, menambah dan mendisiplinkan petugas parkir sehingga keamanan dan kerapihan pengaturan tempat parkir kendaraan terjaga, penambahan jumlah shelter permanen mengantisipasi musim penghujan dan angin, penyediaan anggota polisi yang piket untuk menampung dan menindaklanjuti keluhan dan masalah keamanan yang dialami wisatawan, penambahan jumlah dan jenisnya alat bermain anak, pengelolaan penginapan di Obyek Wisata Pantai Takisung perlu lebih profesional dan penyewaan perahu karet diharapkan dilengkapi dengan jaket pelampung demi keamanan.

2. Diperlukan penyediaan beberapa sarana air mancur untuk membilas, penambahan jumlah dan jenis pertunjukan di panggung hiburan, patroli rutin oleh polisi atau satpam dan petugas penyelamat perlu diadakan di sepanjang pantai, memperbanyak petugas kebersihan dan dijadwal rutin agar pesisir Pantai Takisung tetap terjaga kebersihannya, dan pengawasan pada para wisatawan yang sedang mandi saat laut pasang agar terhindar dari bahaya terseret ombak

\section{DAFTAR PUSTAKA}

[1] Presiden Republik Indonesia. 1990. UndangUndang Pariwisata Nomor 9 Tahun 1990.

[2] Ayoeti, Oka, 1996. Pengantar Ilmu Pariwisata. Angkasa: Bandung. 
[3] Anonim, 2008, Jumlah Data Pengunjung Objek Wisata Pantai Takisung. Dinas Pariwisata Kabupaten Tanah Laut.

[4] Anonim, 2007. Jumlah Data Pengunjung Obyek Wisata Pantai Takisung. Dinas Pariwisata Kabupaten Tanah Laut. 